\title{
Hipotiroidisme kongenital di Bagian Ilmu Kesehatan Anak RS Ciptomangunkusumo Jakarta, tahun 1992-2002
}

\author{
Melda Deliana, Jose RL Batubara, BambangTridjaja, Aman B Pulungan
}

\begin{abstract}
Gejala klinis hipotiroidisme kongenital pada neonatus seringkali tidak begitu jelas dan baru terdeteksi setelah 6-12 minggu. Diagnosis dini sangat penting untuk mencegah timbulnya retardasi mental atau meringankan derajat retardasi mental. Penelitian ini bertujuan untuk mengetahui gambaran klinis awal, laboratorium dan respons terapi awal natrium levotiroksin pada pasien hipotiroidisme kongenital. Data dikumpulkan dari catatan rekam medik kasus-kasus hipotiroidisme kongenital yang berkunjung ke Poliklinik Endokrinologi Anak dan Remaja FKUI/RSCM Jakarta selama kurun waktu 1992-2002. Dalam kurun waktu tersebut terdapat 30 pasien baru, 21 anak (70\%) perempuan dan 9 anak (30\%) laki-laki. Sebagian besar $(53,3 \%)$ didiagnosis pada umur 1-5 tahun. Berdasarkan status antropometri menurut NCHS-WHO ditemukan gizi buruk pada 53,3\% kasus (berat badan/umur), perawakan pendek paa 90\% kasus (tinggi badan/ umur), dan pada $70 \%$ kasus perbandingan berat badan/tinggi badan adalah normal. Gejala klinis tersering saat diagnosis adalah perkembangan motorik terlambat $(83,3 \%)$, konstipasi $(73,3 \%)$, aktivitas menurun $(70 \%)$, makroglosia $(70 \%)$, dan pucat $(70 \%)$. Ditemukan maturasi tulang terlambat (95,5\%), gangguan pendengaran $(22,7 \%)$, gangguan sistem neuromuskular (16,7\%), dan retardasi mental (62,5\%). Pada pemeriksaan skintigrafi dijumpai agenesis tiroid pada 11,1\% kasus. Sebagian besar $(26,7 \%)$ mendapat terapi awal dosis tinggi $(8-10 \mu \mathrm{g} / \mathrm{kg} / \mathrm{hari})$. Gejala klinis berkurang $(36,7 \%)$ dalam 4 minggu dan fungsi tiroid kembali normal $(33,3 \%)$ dalam $1-3$ bulan setelah terapi awal.
\end{abstract}

Kata kunci: asfiksia, hipoksia, iskemia, ensefalopati, bayi baru lahir.

$C_{212}^{1}$ ipotiroidisme kongenital dapat terjadi secara sporadik atau familial, goiter atau non-goiter. ${ }^{1}$ Penelititan ini mengamati hipotiroidisme yang terjadi secara sporadik. Insidens hipotiroidisme kongenital di Amerika 1:3500,2 sedangkan insidens di Indonesia

\footnotetext{
Alamat Korespondensi:

Dr. Jose RL Batubara, Sp.A(K).

Staf Subbagian Endokrinologi. Bagian Ilmu Kesehatan Anak FKUI-RSCM. Jl. Salemba no. 6, Jakarta 10430.

Telepon: 021-3100669. Fax.: 021-3907743.

Dr. Melda Deliana, Sp.A(K)

Bagian Ilmu Kesehatan Anak FK. USU/ RSUP H. Adam Malik Medan. Jl. Bunga Lau No. 17 Medan.

Telepon:. 836 0405, 8360143, 836 034. Fax.: 8361721.
}

berkisar $1: 2916 .{ }^{3}$ Satu dari 60.000-140.000 kasus merupakan hipotiroidisme sekunder atau tertier. ${ }^{2}$ Kadang-kadang gejala klinis hipotiroidisme kongenital tidak begitu jelas pada neonatus dan baru terdeteksi setelah 6-12 minggu. Diagnosis dini sangat penting untuk mencegah timbulnya retardasi mental atau meringankan derajat retardasi mental. ${ }^{4}$ Penelitian menunjukkan bahwa bayi dengan hipotiroidisme kongenital dapat mempunyai perkembangan mental yang normal pada umur 6-7 tahun jika mendapat terapi segera setelah lahir. ${ }^{5}$ Skrining hipotiroidisme terhadap bayi baru lahir sekarang ini secara rutin telah dilakukan di negaranegara maju, ${ }^{6}$ sedangkan di Indonesia baru dalam tahap awal.

Penelitian ini bertujuan untuk mengetahui 
gambaran klinis awal, pemeriksaan penunjang yaitu hemoglobin serum, kolesterol total serum, kadar gula darah sewaktu, fungsi tiroid, usia tulang, skintigrafi, brain evoke responce audiometry (BERA), elektromiografi, ekokardiografi, elektrokardiografi dan pemeriksaan intelligence quotient, serta respons terhadap terapi awal natrium levotiroksin pada pasien hipotiroidisme kongenital.

\section{Metoda}

Penelitian ini merupakan studi deskriptif retrospektif. Data penelitian didapat dari catatan rekam medik kasus hipotiroidisme kongenital yang berkunjung ke Poli Endokrinologi Anak dan Remaja FKUI/RSCM Jakarta dalam kurun waktu 1992-2002. Umur pasien dikelompokkan menurut rekomendasi Guyda dkk. ${ }^{7}$ Status antropometri ditetapkan berdasarkan tabel NCHS-WHO menurut berat badan terhadap umur, tinggi badan terhadap umur dan berat badan terhadap tinggi badan. ${ }^{8}$

Pencatatan gejala klinis saat datang berdasarkan keluhan utama pasien. Pemeriksaan usia tulang dengan nilai 2 standar deviasi (2 SD) di bawah nilai rerata menunjukkan usia tulang terlambat. ${ }^{9}$ Gangguan pendengaran bila ambang pendengaran lebih dari 30 $\mathrm{dB}$ pada satu atau kedua telinga. ${ }^{10}$ Gangguan sistem neuromuskular bila potensial motor unit polifasik memendek dan amplitudo berkurang. ${ }^{11}$ Elektrokardiogram abnormal bila dijumpai voltase rendah dari gelombang P dan T dengan amplitudo kompleks QRS berkurang dan menunjukkan fungsi ventrikel kiri yang buruk, dan atau ada efusi perikard. Derajat efusi perikard ditentukan dengan pemeriksaan ekokardiografi. ${ }^{1,12} \mathrm{Pada}$ pemeriksaan skintigrafi, ditemukannya jaringan tiroid ektopik merupakan petanda disgenesis tiroid. Bila tidak ditemukan jaringan tiroid menunjukkan aplasia tiroid. Kelenjar tiroid yang normal dengan uptake radionuclide normal atau tinggi merupakan indikasi adanya gangguan biosintesis hormon tiroid. ${ }^{1}$ Pemeriksaan tingkat kecerdasan IQ (intelligence quotient) dengan nilai di bawah 85 disebut abnormal. ${ }^{13}$

\section{Hasil}

Selama kurun waktu 1992 hingga 2002, dijumpai 30 kasus hipotiroidisme kongenital, terdiri dari 9 anak laki-laki (30\%) dan 21 anak perempuan (70\%). Sebelas anak merupakan kasus rujukan dari rumah sakit daerah atau swasta, yang lainnya berasal dari Poli Umum Bagian Ilmu Kesehatan Anak RSCM Jakarta.

Pada saat datang pertama kali didapatkan 53,3\% kasus berumur 1-5 tahun. Hanya 3 kasus hipotiroidisme kongenital yang terdiagnosis di bawah umur 3 bulan. Sebagian besar kasus $(53,3 \%)$ dengan gizi buruk berdasarkan penilaian status gizi menurut berat badan menurut umur, perawakan pendek (diukur berdasarkan tinggi badan menurut umur) didapatkan pada $90 \%$ kasus, dan pengukuran berat badan menurut tinggi badan menunjukkan normal pada 70\% anak. (Gambar 1-4)

Gejala klinis tersering yang dikeluhkan saat datang pertama kali adalah perkembangan motorik terlambat $(83,3 \%)$, konstipasi $(73,3 \%)$, aktivitas menurun (70\%), makroglosia (70\%) dan pucat (70\%). (Tabel1)

Pada pemeriksaan kadar hemoglobin serum terhadap 20 pasien, didapatkan $20(66,7 \%)$ anak di antaranya menderita anemia. Hiperkolesterolemia ditemukan pada 1 diantara 7 orang pasien yang diperiksa kadar kolesterolnya. Hanya seorang pasien yang diperiksa kadar gula darah sewaktu dengan hasil rendah. Ditemukan seorang pasien mempunyai kadar

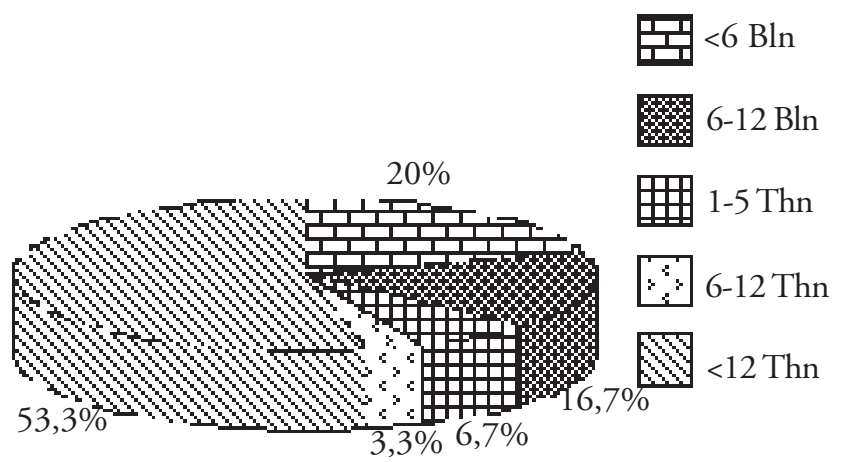

Gambar 1. Sebaran umur pasien saat datang pertama kali

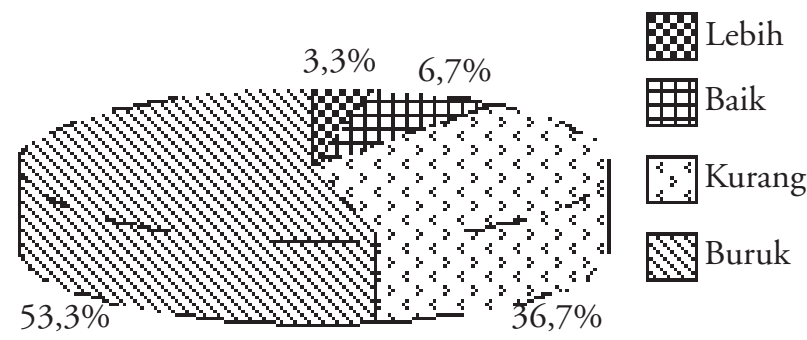

Gambar 2. Sebaran status gizi (berat badan menurut umur) saat diagnosis ditegakkan 


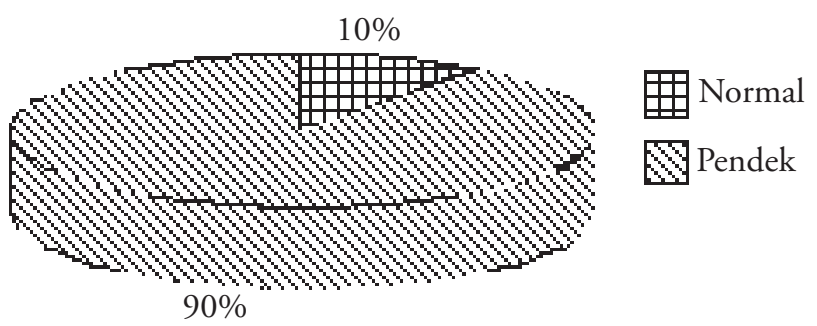

Gambar 3. Sebaran status gizi (tinggi badan menurut umur) saat diagnosis ditegakkan

tiroksin rendah tetapi klinis mendukung diagnosis hipotiroidisme kongenital.

Didapatkan usia tulang terlambat pada $95,5 \%$ kasus, agenesis tiroid pada $11,1 \%$, gangguan pendengaran pada $22,7 \%$, gangguan sistem neuromuskular pada $16,7 \%$, defek septum atrium pada $13,3 \%$, dan hipertrofi ventrikel kanan pada 3,3\% kasus. (Tabel 2)

Pemeriksaan IQ pada 8 kasus menemukan retardasi mental (IQ < 69) pada 5 kasus $(62,5 \%)$, borderline (IQ70-79) pada 2 (25\%) kasus, dan tingkat kecerdasan rata-rata (IQ 90-109) pada 1 (12,5\%) kasus. Kelainan lain yang terdapat bersamaan dengan hipotiroidisme kongenital adalah kelainan jantung bawaan dijumpai pada 5 anak (16,7\%).

Sebagian besar kasus (18 orang) menerima dosis natrium levotiroksin $8-10 \mathrm{mg} / \mathrm{kg} /$ hari pada umur $1-5$

Tabel 1. Gejala klinis saat datang berobat pertama kali

\begin{tabular}{|c|c|c|}
\hline Gejala klinis & Jumlah* & $\%$ \\
\hline Perkembangan motorik terlambat & 25 & 83,3 \\
\hline Konstipasi & 22 & 73.3 \\
\hline Aktivitas menurun & 21 & 70.0 \\
\hline Makroglosia & 21 & 70,0 \\
\hline Pucat & 21 & 70.0 \\
\hline Wajah tipikal** & 18 & 60.0 \\
\hline Problem makan & 16 & 53,3 \\
\hline Hipotonia & 16 & 53,3 \\
\hline Hernia umbikalis & 15 & 50,0 \\
\hline Ubun ubun besar terbuka & 14 & 46,7 \\
\hline Kulit kering & 12 & 40,0 \\
\hline Ikterus fisiologis $>3$ hari & 6 & 20,0 \\
\hline Berat lahir $>3500 \mathrm{~g}$ & 5 & 16.7 \\
\hline Kutis marmorata & 4 & 13,3 \\
\hline Perkembangan bicara terlambat & 3 & 10,0 \\
\hline Masa gestasi $>40$ minggu & 2 & 6,7 \\
\hline
\end{tabular}

* Satu orang dapat mempunyai lebih dari satu gejala klinis, **Wajah tipikal=wajah sembab dan ekspresi kesan bodoh

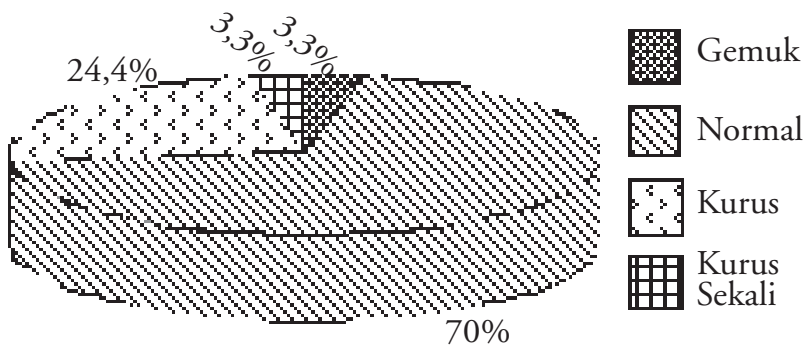

Gambar 4. Sebaran status gizi (berat badan menurut tinggi badan) saat diagnosis ditegakkan

tahun. Pada kelompok ini, gejala klinis berkurang dalam 4 minggu terapi awal didapatkan pada 11 kasus dan fungsi tiroid kembali normal dalam 1-3 bulan setelah didapatkan pada 10 kasus. Terdapat 4 kasus yang tidak diperiksa fungsi tiroid setelah pemberian terapi hormon tiroid. (Tabel $3-5$ )

Tabel 2. Pemeriksaan penunjang saat hipotiroidisme kongenital ditegakkan diagnosis

\begin{tabular}{|c|c|c|}
\hline Pemeriksaan & $\mathrm{n}$ & $\%$ \\
\hline \multicolumn{3}{|l|}{ Usia tulang } \\
\hline - terlambat & 21 & 95,5 \\
\hline - sesuai & 1 & 4,5 \\
\hline \multicolumn{3}{|l|}{ Skintigrafi } \\
\hline - agenesis & 1 & 11,1 \\
\hline - tidak jelas & 8 & 88,9 \\
\hline \multicolumn{3}{|c|}{ BERA (brain evoke respons audiometry) } \\
\hline - abnormal & 5 & 22,7 \\
\hline - normal & 17 & 77,3 \\
\hline \multicolumn{3}{|l|}{ Elektromiografi } \\
\hline - abnormal & 2 & 16,7 \\
\hline - normal & 10 & 83,3 \\
\hline \multicolumn{3}{|l|}{ Ekokardiografi: } \\
\hline - defek septum atrium & 4 & 13,3 \\
\hline - tidak diperiksa & 26 & 86,7 \\
\hline \multicolumn{3}{|l|}{ Elektrokardiografi } \\
\hline - hipertrofi ventrikel kanan & 1 & 3,3 \\
\hline - tidak diperiksa & 29 & 96,7 \\
\hline \multicolumn{3}{|l|}{ Diskusi } \\
\hline \multicolumn{3}{|c|}{$\begin{array}{l}\text { Pada penelitian ini diagnosis hipotiroidisme kongenital } \\
\text { sebagian besar }(53,3 \%) \text { ditegakkan pada umur } 1-5 \\
\text { tahun, hanya } 3 \text { pasien diagnosis ditegakkan sebelum } \\
\text { umur } 3 \text { bulan. Padahal jika pemberian terapi hormon }\end{array}$} \\
\hline
\end{tabular}


Tabel 3. Distribusi pengobatan awal natrium levotiroksin pada berbagai dosis menurut umur

\begin{tabular}{lccccc}
\hline \multirow{2}{*}{ Umur } & \multicolumn{5}{c}{ Dosis $(\mu \mathrm{g} / \mathrm{kg} / \mathrm{hari})$} \\
\cline { 2 - 6 } & $>8-10$ & $>6-8$ & $>5-6$ & $4-5$ & $2-3$ \\
\hline$<6$ bulan & 5 & 0 & 1 & 0 & 0 \\
6-12 bulan & 5 & 0 & 0 & 0 & 0 \\
1-5 tahun & 8 & 6 & 1 & 1 & 0 \\
6-12 tahun & 1 & 0 & 1 & 0 & 0 \\
$>12$ tahun & 0 & 0 & 1 & 0 & 0 \\
\hline
\end{tabular}

Tabel 4. Jumlah kasus dengan gejala klinis berkurang setelah terapi awal

\begin{tabular}{lccccc}
\hline Dosis & \multicolumn{5}{c}{ Lama terapi (minggu) } \\
\cline { 2 - 6 }$(\mu \mathrm{g} / \mathrm{kg} / \mathrm{hari})$ & 1 & 2 & 3 & 4 & $>4$ \\
\hline $8-10$ & 0 & 2 & 4 & 11 & 1 \\
$6-8$ & 1 & 1 & 3 & 1 & 0 \\
$5-6$ & 0 & 1 & 2 & 1 & 1 \\
$4-5$ & 0 & 1 & 0 & 0 & 0 \\
$2-3$ & 0 & 0 & 0 & 0 & 0 \\
\hline Jumlah & 1 & 5 & 9 & 13 & 2 \\
\hline
\end{tabular}

Tabel 5.Jumlah kasus dengan fungsi tiroid normal setelah terapi awal

\begin{tabular}{lcccc}
\hline $\begin{array}{l}\text { Dosis } \\
(\mu \mathrm{g} / \mathrm{kg} / \text { hari })\end{array}$ & \multicolumn{4}{c}{ Lama terapi (bulan) } \\
\cline { 2 - 5 } & $1-3$ & $4-6$ & $6-8$ & $>8$ \\
\hline $8-10$ & 10 & 5 & 2 & 0 \\
$6-8$ & 2 & 2 & 0 & 1 \\
$5-6$ & 2 & 1 & 0 & 0 \\
$4-5$ & 1 & 0 & 0 & 0 \\
$2-3$ & 0 & 0 & 0 & 0 \\
\hline Jumlah & 15 & 8 & 2 & 1
\end{tabular}

tiroid diberikan secara adekuat sebelum umur 3 bulan, anak-anak tersebut akan mencapai perkembangan mental yang normal. ${ }^{714,15}$

Secara garis besar, gangguan tumbuh kembang pada hipotiroidisme kongenital adalah gangguan terhadap pertumbuhan fisik, pertumbuhan dan kematangan susunan saraf pusat dan proses kedewasaan (pubertas). ${ }^{16}$ Pada penelitian ini ditemukan gangguan pertumbuhan fisik berupa gizi buruk pada 53,3\% kasus, perawakan pendek pada $90 \%$, sedangkan perhitungan berat badan menurut tinggi badan ditemukan normal pada 70\% kasus. Hal ini menunjukkan bahwa sebagian besar pasien mempunyai rasio berat badan menurut tinggi badan yang meningkat dan hal ini sesuai dengan kelainan endokrinologi. ${ }^{17}$

Saat gejala klinis hipotiroid sudah tampak secara bertahap, diagnosis sering sudah terlambat. ${ }^{1}$ Pada penelitian ini gejala klinis tersering saat diagnosis adalah perkembangan motorik terlambat $(83,3 \%)$, konstipasi $(73,3 \%)$, aktivitas menurun (70\%), makroglosia (70\%) dan pucat (70\%). Gejala dan tanda klinis yang sering dijumpai pada hipotiroidisme kongenital menurut literatur yaitu ikterus yang lama akibat keterlambatan maturasi konjugasi glukoronida, problem makan, kesulitan bernafas sebagian disebabkan adanya makroglosia, konstipasi yang biasanya tidak respons terhadap pengobatan, perut membesar disertai hernia umbilikalis, serta pertumbuhan dan perkembangan terlambat. ${ }^{1,17}$ Terdapat sedikit perbedaan gejala klinis pada penelitian ini karena sebagian besar $(53,3 \%)$ didiagnosis saat berumur 1-5 tahun.

Hormon tiroid mempunyai efek pada hampir seluruh jaringan tubuh yaitu mengatur kemampuan untuk menstimulasi metabolisme basal atau kalorigenesis. ${ }^{18}$ Anemia (66,7\%), hiperkolesterolemia $(14,3 \%)$ dan kadar gula darah sewaktu yang rendah pada seorang pasien, ditemukan pada penelitian ini. Anemia pada hipotiroid disebabkan oleh gangguan sintesis hemoglobin, gangguan absorbsi besi, asam folat dan vitamin B12, sedangkan sintesis kolesterol dan konversi metaboliknya serta metabolisme karbohidrat mengalami gangguan pada pasien defisiensi hormon tiroid. ${ }^{12,18}$ Maturasi tulang pada hipotiroidisme kongenital umumnya terlambat, disebabkan oleh adanya gangguan metabolisme tubuh. ${ }^{19}$ Pada penelitian ini ditemukan 95,5\% kasus mempunyai maturasi tulang terlambat.

Pada populasi bayi hipotiroidisme kongenital yang tidak diobati secara dini dan adekuat, didapatkan problem perkembangan pendengaran dan keterlambatan bicara sampai dengan problem perhatian dan tingkah-laku. ${ }^{15}$ Pada penelitian ini dijumpai 5 anak $(22,7 \%)$ dengan gangguan pendengaran (1 orang tuli sensorik dan 4 orang tuli konduktif). Hubungan antara hormon tiroid dan fungsi pendengaran telah dikenal pada pasien dengan resisten hormon tiroid, sindrom Pendred dan kretinisme endemik. ${ }^{20}$ Gangguan pendengaran pada hipotiroidisme kongenital pada 
umumnya jenis sensorineural, namun dapat juga bersifat campuran. Sedangkan pada sindrom Pendred dijumpai gangguan pendengaran jenis sensorineural. ${ }^{21}$

Banyak juga penderita yang mengeluh gejala sistem neuromuskular misalnya kelemahan otot, kram otot dan parestesia. ${ }^{12}$ Pada penelitian ini, 2 anak (16,7\%) menunjukkan kelainan pada pemeriksaan EMG yaitu kecepatan pergerakan motorik berkurang dengan refleks relaksasi otot yang lambat. ${ }^{11}$ Kelainan jantung bawaan didapat pada 5 anak (16,7\%). Bayi dengan hipotiroidisme kongenital, 3-7\% mengalami kelainan bawaan terutama kelainan septum atrial dan ventrikular. ${ }^{2}$ Manifestasi kardiovaskular yang timbul pada hipotiroidisme biasanya berupa gangguan kontraksi otot jantung, bradikardia dan berkurangnya cardiac output. ${ }^{12}$ Penyebab yang sering pada hipotiroidisme kongenital adalah atiroid (45\%), tiroid ektopik dan dishormonogenesis. ${ }^{22}$ Pada penelitian ini, agenesis tiroid ditemukan pada satu anak.

Terdapat perbedaan hasil penelitian ini dengan penelitian sebelumnya di Bagian IKA FKUI /RSCM Jakarta, ${ }^{23}$ yang menunjukkan jumlah pasien yang mengalami gangguan pendengaran dan sistem neuromuskular pada penelitian ini lebih sedikit. Hal ini disebabkan karena penelitian dilakukan dalam kurun waktu yang berbeda dan tidak semua pasien dilakukan pemeriksaan BERA. Hipotiroidisme kongenital dapat didiagnosis banding dengan sindrom Down, suatu keadaan lain yang menyebabkan perawakan pendek dan gambaran wajah yang khas. ${ }^{19}$

Terapi hipotiroidisme kongenital berupa pemberian preparat hormon tiroid yaitu natrium levotiroksin dengan dosis yang dianjurkan menurut umur dan berat badan. ${ }^{17}$ Tujuan terapi adalah untuk mencapai kadar T4 dalam batas $10-16 \mu \mathrm{g} / \mathrm{dl}$ dan secara sekunder mencapai kadar TSH dalam batas normal. ${ }^{24}$ Bila terapi sudah diberikan pada hipotiroidisme kongenital, maka kadar tiroksin (T4) dan tirotropin (TSH) harus diulang setiap bulan sampai mencapai kadar normal, kemudian setiap 3 bulan sampai tahun ke-3, setelah itu kadar T4 dan TSH diperiksa setiap 6 bulan. ${ }^{2}$

Terapi optimal untuk mencapai eutiroidisme dimulai sebelum umur 3 minggu dengan terapi awal di atas $9,5 \mu \mathrm{g} / \mathrm{kg} /$ hari, akan mencapai kadar FT4 dalam batas atas yang normal pada tahun pertama. Selanjutnya pasien hipotiroidisme kongenital dapat mencapai perkembangan mental normal pada saat umur 10-30 bulan. ${ }^{25,26}$ Pengobatan pada hipotiroidisme kongenital diberikan seumur hidup. ${ }^{1}$ Sebagian besar pasien $(26,7 \%)$ pada penelitian ini diberikan terapi awal dosis tinggi $(8-10 \mu \mathrm{g} / \mathrm{kg} / \mathrm{hari})$, dan gejala klinis berkurang sebagian besar $(36,7 \%)$ dalam 4 minggu setelah terapi awal.

Pemberian dosis awal yang tinggi $12-17 \mathrm{mg} / \mathrm{kg} /$ hari, akan meningkatkan kadar T4 dan FT4 sesuai target dalam waktu 3 hari dan kadar TSH kembali normal dalam 2 minggu setelah terapi awal. ${ }^{25}$ Pada penelitian ini, fungsi tiroid kembali normal pada 10 anak $(33,3 \%)$ dalam 1-3 bulan setelah terapi awal, dan pada 6 anak (20\%) fungsi tiroid kembali normal dalam 1 bulan setelah terapi awal. Sedangkan sisanya baru dapat dilakukan pemeriksaan laboratorium fungsi tiroid pada bulan ke-2 atau ke-3 karena masalah biaya.

Secara kuantitatif, sebuah studi menunjukkan keterlambatan terapi dapat menurunkan IQ beberapa angka perminggu segera setelah bayi lahir. Keterlambatan terapi dalam waktu 5-6 bulan berhubungan dengan IQ sekitar $70 .{ }^{27}$ Demikian pula pada penelitian ini, kebanyakan penderita terlambat mendapat terapi yaitu pada umur $1-5$ tahun $(53,3 \%)$. Dari 8 pasien yang diperiksa perkembangan mentalnya menjelang usia sekolah, ditemukan 5 anak $(62,5 \%)$ mengalami retardasi mental (IQ <69), dan 2 pasien $(25 \%)$ mempunyai IQ borderline (IQ70-79). Hanya 1 pasien $(12,5 \%)$ mempunyai tingkat kecerdasan rata-rata (IQ 90-109), hal ini disebabkan karena pasien ini mulai mendapat terapi pada umur 5 bulan.

\section{Kesimpulan}

Sebagian besar penderita $(53,3 \%)$ terlambat didiagnosis yaitu pada umur 1-5 tahun. Gejala klinis tersering saat diagnosis adalah perkembangan motorik terlambat $(83,3 \%)$, konstipasi $(73,3 \%)$, aktivitas menurun (70\%), makroglosia (70\%), pucat $(70 \%)$. Ditemukan anemia $(66,7 \%)$, hiperkolesterolemia $(14,3 \%)$, kadar gula darah sewaktu rendah $(3,3 \%)$, maturasi tulang terlambat $(95,5 \%)$, agenesis tiroid $(11,1 \%)$, gangguan pendengaran $(22,7 \%)$, gangguan sistem neuromuskular (16,7\%), kelainan jantung bawaan $(16,7 \%)$ dan retardasi mental $(62,5 \%)$. Pada sebagian besar $(26,7 \%)$ diberikan terapi awal dosis tinggi $(8-10 \mathrm{mg} / \mathrm{kg} / \mathrm{hari})$. Gejala klinis berkurang $(36,7 \%)$ dalam 4 minggu dan fungsi tiroid kembali normal $(33,3 \%)$ dalam 1-3 bulan setelah terapi awal. 


\section{Saran}

Untuk menghindari terjadinya retardasi mental pada penderita hipotiroidisme kongenital, sebaiknya program skrining nasional dilakukan. Monitor laboratorium fungsi tiroid dilakukan setiap bulan setelah awal terapi dan pada setiap perubahan dosis. Pada setiap penderita hipotiroidisme kongenital sebaiknya dilakukan pemeriksaan tambahan BERA, elektromiografi dan tes IQ. Skor hipotiroidisme kongenital masih relevan untuk digunakan pada bayi baru lahir sampai usia kurang dari 3 bulan.

\section{Daftar pustaka}

1. Di George AM, La Franchi S. Disorders of thyroid. Dalam: Behrman RE, Kliegman RM, Arvin AM, penyunting. Nelson textbook of pediatrics. Edisi ke-15. Philadelphia: Sounders, 1996. h. 1587-605.

2. Bourgeois MJ, Varma Surendra. Congenital hypothyroidism. Didapat dari URL:http//www.emedicine.com/ped/ topic 501 htm. Disitasi pada hari Rabu, 18 Juni 2003.

3. Rustama DS. Pilot study skrining hipotiroidisme kongenital di propinsi Jawa Barat dan DKI Jakarta. Disampaikan pada pertemuan Executive Summary Departemen Kesehatan RI, Jakarta 19 Februari 2003.

4. Sularyo TS, Kadim M. Retardasi mental. Sari Pediatri 2000; 2:170-7.

5. Roberts HE, Moore CA, Fernhoff PM, Brown AL and Khoury MJ. Population study of Congenital Hypothyroidism and Associated Birth Defects, Atlanta, 19791992. Am J Med Genet 1997; 71:29-32.

6. Fisher DA. Disorders of the thyroid in the newborn and infant. Dalam: Sperling MA, penyunting. Pediatric endocrinology. Edisi ke-2. Philadelphia: Saunders, 2002. h. 161-85.

7. Guyda H. Therapy of congenital hypothyroidism evaluation of biochemical parameters. Dalam: Burrow GN, Dussault JH, penyunting. Neonatal thyroid screening. New York: Raven Press, 1980. h. 247. Dsunting dari Dussault JH. Congenital hypothyroidism. Dalam: Ingbar $\mathrm{SH}$, Braverman LE, penyunting. Werner's the thyroid a fundamental and clinical text. Edisi ke-5. New York: JB Lippincott, 1986. h. 1399-404.

8. Keputusan Menteri Kesehatan RI No. 920/Menkes/SK/ VIII/2002 tentang klasifikasi status gizi anak balita.

9. Greulich WW, Pyle SI. The rationale and technique of assessing the development status of children from roentgenograms of the hand and wrist. Dalam: Greulich WW, Pyle SI, penyunting. Radiographic atlas of skeletal development of the hand and wrist. Stanford: Stanford University Press, 1950. h. 1-34.

10. Behrman RF, Nelson WE, Vaughan VC. Disorder of hearing, speech, and language. Dalam: Behrman RF, Nelson WE, Vaughan VC,penyunting. Nelson textbook of pediatric. Edisi ke-13. Philadelphia: Saunders, 1987. h. $95-101$.

11. Enderson WE, Xu L. Endocrin myopathies. Didapat dari URL:http://www.emedicine.com/neuro/topic 125.htm. Disitasi pada hari selasa 17 Juni 2003.

12. Greenspan FS. The thyroid gland. Dalam: Greenspan FS, Strewler GJ, penyunting. Basic and Clinical Endocrinology. Edisi ke-5. London: Appleton dan Lange, 1997. h. 192-262.

13. Passat J. Kelainan perkembangan. Dalam: Soetomenggolo TS, Ismael S, penyunting. Buku ajar neurologi anak. Jakarta: IDAI, 1999. h. 104-36.

14. Assin MS. Congenital hypothyroidism. Dalam: Assin MS, Rukman J, Dahlan A, Batubara JRL, penyunting. Masalah penyimpangan pertumbuhan somatik dan perkembangan seksual pada anak. Naskah lengkap PKB Ilmu Kesehatan Anak ke XIII FK-UI; 1986 21-22 Februari; Jakarta: Balai Penerbit FKUI, 1986.

15. Rapaport R. Congenital hypothyroidsm: Expanding the spectrum. J Pediatric 2000; 136:10-2.

16. Soetjiningsih. Kretin. Dalam: IG.N. Gde Ranuh, penyunting. Tumbuh kembang anak. Jakarta: Penerbit Buku Kedokteran EGC, 1998. h. 203-10.

17. Dallas Js, Foley TP. Hypothyroidism. Dalam: Lifshitz F, penyunting. Pediatric endocrinology. Edisi ke-3. New York: Marcel Dekker Inc, 1996. h. 391-9.

18. Griffin JE. The thyroid. Dalam: Griffin JE, Ojeda SR, penyunting. Textbook of endocrine physiology. Edisi ke3. New York: Oxford University Press, 1996. h. 260-83.

19. Gotlin RW, Kappy MS, Slover RH. Endocrine disorders. Dalam: Hay WW, Groothuis JR, Hayward AR, Levin MJ, penyunting. Current pediatric diagnosis \& treatment. Edisi ke-13. New Jersey: Appleton dan Lange, 1997. h. 818-56.

20. Rovet J, Walker W, Bliss B, Buchanan L, Ehrlich R. Longterm sequelae of hearing impairment in congenital hypothyroidism. J Pediatric 1996; 128:776-83.

21. Harner SG. Otolaringology and endocrine disease. Dalam: Becker KL, penyunting. Principles and practice of endocrinology and metabolism. Edisi ke-2. Philadelphia: Lippincott, 1995. h. 1817-21.

22. Henry G, Sobki SH, Othman JM. Screening for congenital hypothyroidism. Saudi Med J 2002; 23:529-35.

23. Niken Prita Yati, Batubara JRL, Bambang Tridjaja, Pulungan AB. Gangguan pendengaran pada hipotiroid kongenital. Dalam: Firmansyah A, Trihono PP, Oswari H, Nurhamzah W, Darmawan BS, penyunting. Abstrak KONIKA XI. Jakarta 1999 4-7 Juli. Jakarta: IDAI Pusat, 1999.

24. Hopwood NJ. Treatment of the infant with congenital hypothyroidism. J Pediatr 2002; 141:752-4.

25. Selva KA, Mandel SH, Rien L, dkk. Initial treatment dose of L-thyroxine in congenital hypothyroidism. J Pediatr 2002; 14:786-92.

26. Bongers-Schokking JJ, Koot HM, Wiersma D, dkk. Influence of timing and dose of thyroid hormone replacement on development in infants with congenital hypothyroidsm. J Pediatr 2000; 136:292-7.

27. Fisher DA. The importance of early management in optimizing IQ in infants with congenital hypothyroidism. J Pediatr 2000; 136:273-4. 